\title{
Cognitive, Affective, and Conative Attitude of Farmers to Rice Farming Insurance (RFI) Program in Tanah Datar District, West Sumatera Province, Indonesia
}

\author{
Siska Handayani ${ }^{a}$, Rudi Febriamansyah ${ }^{b^{*}}$, Mahdi $^{b}$ \\ ${ }^{a}$ Department of Rural and Regional Development, Graduate Program, Universitas Andalas, Padang 25163, West \\ Sumatera, Indonesia \\ ${ }^{b}$ Faculty of Agriculture, Universitas Andalas, Padang 25163, West Sumatera, Indonesia
}

\section{ARTICLE INFORMATION}

Article history:

Received: 23 July 2019

Revised: 30 September 2019

Accepted: 25 November 2019

Keywords:

Farmer Attitudes, Cognitive, Affective, Conative, Rice Farming Insurance (RFI) Program

\section{Correspondence:}

*r_febriamansyah@agr.unand.ac.id

\begin{abstract}
A B S T R A C T
The Ministry of Agriculture has implemented the Rice Farming Insurance (RFI) Program in Indonesia since 2015 to protect farmers from possible loss of crop failure due to various potential disasters such as floods, drought, pests, etc. Although it has been immensely encouraged by the relevant field agencies, this RFI program was unsuccessful. The land area that follows the RFI program in Tanah Datar District decreased

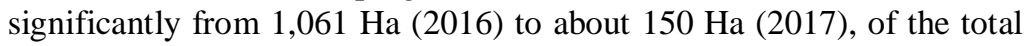
target area of 2,300 Ha. This study is conducted to find factors that lead to decreased farmer participation in this RFI program, mainly by studying how the government has done the socialization process and how farmers' actual attitude towards this RFI program? By applying qualitative and quantitative approaches, this study obtained the empirical facts that the socialization process, done by relevant stakeholders, including government, private and community leaders, and farmers, not so intensified. The attitude of farmers to this program showed that, in the cognitive aspects, most farmers in all five categories still do not fully understand and confident about the RFI program. It is similar to their affective elements; most farmers in the five categories have not yet determined attitudes, whether they like or dislike the RFI program. Meanwhile, only in terms of their conative aspects, mostly farmers of all categories are eager to learn more and become the RFI program participant.
\end{abstract}

(C)2019

\section{INTRODUCTION}

Technically, farmers will always face agriculture business activities with a reasonably high risk of uncertainty. The risk of these uncertainties includes the rate of crop failure due to natural disasters, such as floods, droughts and pests, and diseases as the consequences of global climate change and the market price risks (Pasaribu, 2014). This risk is likely to cause a decrease in production, damage, and decline in quality of products, which can cause a reduction in farm income of farmers, traders, and other businesses. 
Following the mandate of Law Number 19/2013 on Protection and Empowerment of Farmers, the Ministry of Agriculture has issued a policy in the form of Permentan No.40/2015 on the Facilitation of Agricultural Insurance to help farmers cope with the possibility of future losses of those risks. In Permentan No.40, agricultural insurance is a risk transfer scheme to provide compensation due to loss of farming so that the sustainability of farming can be assured. In this regard, the ministry has declared an insurance program to ensure rice production sustainability called the Rice Farming Insurance (RFI) Program. RFI program provides a guarantee against damage to rice crops due to floods, droughts, and pest/disease attacks.

In the province of West Sumatra, rice is an agricultural commodity facing frequent production failures. In 2016, the BPTPHP reported the pest/disease attacks to the paddy field in West Sumatra province that reached as much of 4,479 Ha. Moreover, 3,121 Ha of rice farming land were damaged by floods, $224 \mathrm{Ha}$ of land to crop failure due to drought, and $5 \mathrm{Ha}$ of paddy field had landslides. If totaled in 2016 reached 8,283.24 Ha of land rice farming in West Sumatra that suffered losses due to pests, floods, droughts, and landslides ([BPTPHP] Balai Perlindungan Tanaman Pangan Hortikultura dan Perkebunan Provinsi Sumatera Barat, 2017).

Therefore, in 2016, the West Sumatra provincial government targeted $36,000 \mathrm{Ha}$ of land farmers to follow the RFI program. Unfortunately, there is only about 28,394.86 Ha (78.6\%) followed this RFI program. Even in 2017, there was a decreased land area that follows the RFI program. There are only about $15,266.55 \mathrm{Ha}$ (43.62\%) from the target area of 35,000 Ha implemented this RFI program

The District of Tanah Datar is a center of rice production in West Sumatra province with a paddy-field area of $22,944 \mathrm{Ha}$ or around $10 \%$ of the total paddy area in West Sumatra Province $(230,175.8 \mathrm{Ha})$. Nevertheless, the District of Tanah Datar includes a region prone to disruption of production, primarily due to pests or drought and landslides ([BPTPHP] Balai Perlindungan Tanaman Pangan Hortikultura dan Perkebunan Provinsi Sumatera Barat, 2017).

RFI program in the District of Tanah Datar has been implemented since 2016, covering the entire district by involving as many as 44 farmers' groups. Completing the
RFI program in this district is not different from the completion at the Provincial level. The completion of the RFI program in this district was also only $1,061.65 \mathrm{Ha}$ (46.1\%) from the target area of 2,300 $\mathrm{Ha}$. It declined in 2017 to be around $6.53 \%$ only of the target area covered by this RFI program. ([DTPHP] Dinas Tanaman Pangan Hortikultura dan Perkebunan Provinsi Sumatera Barat., 2016)

In general, the above circumstances have shown that a decrease in land area covered by the RFI program may relate to the attitude or action of farmers who have quit from the RFI program. Theoretically, the attitudes or actions of that farmers are representing their opinions, their beliefs, their feeling about the object or situation that often occurs, then provide them as the basis for them to make a response or behave/act in a way that particular choice (Walgito, 2003).

Moreover, based on this conception, there are three components of attitudes; cognitive, affective, and conative, which drive the thinking process before someone decides their choice. The level of those three components will then create someone's attitude to make decisions about the object or situation. Meanwhile, a farmer's attitude or action will also be formed after the related parties provide the program's information. Socialization of the RFI program has been given to farmers to affect components of the knowledge/belief (cognitive), feeling (affective), and a tendency to act (conative) of farmers to accept the RFI program.

Therefore, based on the above background, this study was conducted to explore how the process of socialization has been done for the success of the RFI program in the District of Tanah Datar and analyze the level of farmers attitude in five categories of farmers (1) the farmers who have claimed the insurance, (2) those who have quit from the RFI program, (3) farmers who keep up with the RFI program, (4) new farmers who join the RFI, and (5) those who do not or have not yet participated in the RFI program.

\section{RESEARCH METHODS}

This study used a mixed method of descriptive, qualitative, and quantitative researches. A semistructured interview is conducted with key informants to collect relevant data on the RFI program's socialization process. While analyzing farmers' attitudes towards the 
RFI program, data collection is done by structured interviews with respondents of farmers using a questionnaire (questionnaire).

This study's population was rice farmers in Tanah Datar who have received the RFI program's socialization (502 farmers). They are living in three Nagaris; Nagari Gurun (at the subdistrict of Sungai Tarab), Nagari Tabek (at the subdistrict of Pariangan), and Nagari Padang Ganting (at the subdistrict of Padang Ganting). This study has selected as many as 223 respondents from this population

Table 1. Distribution of survey samples

\begin{tabular}{|c|c|c|}
\hline & Categories & $\begin{array}{c}\text { Number Of } \\
\text { Samples }\end{array}$ \\
\hline I & $\begin{array}{l}\text { Farmers who have } \\
\text { claimed the damage }\end{array}$ & 22 \\
\hline II & $\begin{array}{l}\text { Farmers that have } \\
\text { stopped the RFI } \\
\text { program }\end{array}$ & 83 \\
\hline III & $\begin{array}{l}\text { Farmers who continue } \\
\text { to follow the RFI } \\
\text { program }\end{array}$ & 12 \\
\hline IV & $\begin{array}{l}\text { New farmers who join } \\
\text { the program }\end{array}$ & 103 \\
\hline V & $\begin{array}{l}\text { Farmers who do not } \\
\text { follow the } \\
\text { program }\end{array}$ & 21 \\
\hline
\end{tabular}

using Slovin's formula with a $95 \%$ confidence level. The next election based on the number of farmers samples taken five categories of farmers in proportion, with distribution as follows

The observed variables are the attitude components of mechanism of implementation of the RFI program and (5) services in the RFI program. This study used Likert scale models with five scale levels (from 1 to 5 ) to measure each component of those five object attitudes.

This study used an analytical method of weighting and ranking the value score of all answers to all components of those five objects of attitudes.

Weights are divided evenly on each component of the attitude and the attitude object. Furthermore, leveling achievement to each attitude's value is spread into five levels: very-low, low, neutral, high, and very high, based on the Minimum and Maximum values for each component of attitudes.

\section{RESULTS AND DISCUSSION}

\section{Socialization Rice Farming Insurance Program (RFI) in Tanah Datar District}

\section{Socialization at the District level}

According to the key informants, the initial phase of RFI before registration of participants is a socialization program involving stakeholders in the RFI program, namely PT Jasindo branch Bukit Tinggi as an insurance company, the supervisor extension districts, extension workers, farmers, and leaders of farmer groups. This socialization of the RFI program was organized by the Agriculture Office of Tanah Datar District in May 2016 and May 2017 at the Department of Agriculture Hall of Tanah Datar.

The officer from the Agriculture Office of Tanah Datar

Table 2. Assessment weighting based on the number revelation attitude and a score of 5 Likert scale

\begin{tabular}{|c|c|c|c|c|c|c|c|c|c|c|c|c|}
\hline \multirow[b]{2}{*}{ Object of attitude } & \multicolumn{4}{|c|}{ Cognitive $($ Weight $=33.3 \%)$} & \multicolumn{4}{|c|}{ Affective (Weight $=33.3 \%$ ) } & \multicolumn{4}{|c|}{ Conative $($ Weight $=33.3 \%)$} \\
\hline & Q & Weight & Min & Max & Q & Weight & Min & Max & Q & Weight & Min & Max \\
\hline risk & 5 & 6.67 & 0.33 & 1.67 & 0 & 0 & 0 & 0 & 0 & 0 & 0 & 0 \\
\hline benefit & 3 & 6.67 & 0.20 & 1.00 & 3 & 8.33 & 0.25 & 1.25 & 3 & 8.33 & 0.25 & 1.25 \\
\hline Premium & 3 & 6.67 & 0.20 & 1.00 & 3 & 8.33 & 0.25 & 1.25 & 3 & 8.33 & 0.25 & 1.25 \\
\hline Mechanism & 5 & 6.67 & 0.33 & 1.67 & 5 & 8.33 & 0.42 & 2.08 & 4 & 8.33 & 0.33 & 1.67 \\
\hline Service & 3 & 6.67 & 0.20 & 1.00 & 6 & 8.33 & 0.50 & 2.50 & 6 & 8.33 & 0.50 & 2.50 \\
\hline total & 19 & 33.3 & 1.27 & 6.33 & 17 & 33.3 & 1.42 & 7.08 & 16 & 33.3 & 1.33 & 6.67 \\
\hline
\end{tabular}

Note: $Q=$ number of statements on each object attitude rated

cognitive, affective, and conative of farmers to the five object attitude of the RFI program; (1) the risk of paddy farming; (2) the benefits of the RFI program; (3) the premiums paid by farmers for RFI program; (4) the and the head of PT Jasindo Branch Bukit Tinggi presented the RFI program's detailed information and guidance for farmers to follow this insurance program. The material presented in this activity are as follows; 
1. Production losses due to pest and natural disasters that rice farmers can experience,

2. The potential risk of pest/disease attacks that have occurred in West Sumatra, and

3. The detailed information of the RFI program

The presentation of RFI program information activities in Tanah Datar is conducted with a combination of several methods. The first method is delivering the material in one direction by the speaker using a laptop and a projector so that participants can see the RFI program's material. Besides, participants were also given printed materials of the RFI program. The next session was a question-and-answer discussion session. The combination of those methods of socialization done by the government officers and related stakeholders has shown the intention and motivation for the program's success.

\section{Socialization at the farm level}

After counseling and socialization at the district level, the village extension workers conveyed and disseminated information about the RFI program to farmers in farmer groups in each village extension work area. However, socialization activities such as attendance or collection of socialization materials. The dissemination of information about the RFI program was conducted during the regular meeting of extension workers, especially at the time of planting season or other occasions, at the farmer's house or in the field site.

\section{The analysis of farmer's attitude component}

\section{The cognitive attitude of farmers}

The cognitive attitude (CA) is one of three components forming attitudes related to knowledge, understanding, and beliefs. The result of the CA level of farmers towards the RFI program is presented in Table 3. In general, the table shows that the $\mathrm{CA}$ of farmers is still relatively neutral towards the RFI program.

High cognitive attitude only in the third category of farmers who have decided to continue the RFI for their farming land. The high value of CA at the $3^{\text {rd }}$ category of farmers is mainly due to the very high valuation on the object of his attitude toward the RFI program's mechanism, followed by the high response on the benefits and the premiums to be paid.

Table 3. The cognitive attitude of farmers towards the RFI program

\begin{tabular}{|c|c|c|c|c|c|c|c|}
\hline \multirow[b]{2}{*}{ No } & \multirow[b]{2}{*}{ Categories } & \multicolumn{5}{|c|}{ The cognitive attitude of farmers to each object of RFI program } & \multirow[b]{2}{*}{$\begin{array}{l}\text { Cognitive } \\
\text { Total }\end{array}$} \\
\hline & & $\begin{array}{l}\text { Risk } \\
\text { farming } \\
\text { paddy }\end{array}$ & $\begin{array}{l}\text { Benefit } \\
\text { program }\end{array}$ & $\begin{array}{l}\text { The premiums } \\
\text { paid by farmers }\end{array}$ & $\begin{array}{l}\text { Mechanically } \\
\text { RFI }\end{array}$ & $\begin{array}{l}\text { Service } \\
\text { of RFI }\end{array}$ & \\
\hline 1 & $\begin{array}{l}\text { Farmers who have } \\
\text { claimed the damage } \\
(n=22)\end{array}$ & neutral & neutral & high & high & low & neutral \\
\hline 2 & $\begin{array}{l}\text { Farmers that have } \\
\text { stopped the RFI } \\
\text { program }(n=83)\end{array}$ & neutral & neutral & neutral & high & neutral & neutral \\
\hline 3 & $\begin{array}{l}\text { Farmers who continue } \\
\text { to follow the RFI } \\
\text { program }(n=12)\end{array}$ & neutral & high & high & Very high & low & high \\
\hline 4 & $\begin{array}{l}\text { New farmers who join } \\
\text { the program }(n=103)\end{array}$ & neutral & neutral & high & high & low & neutral \\
\hline 5 & $\begin{array}{l}\text { Farmers who do not } \\
\text { follow the RFI program } \\
(n=21)\end{array}$ & neutral & low & neutral & low & Very low & low \\
\hline
\end{tabular}

based on interviews with village extension workers, the socialization at the farm level is not in a formal activity in a formal group meeting, but only occasional visits to the group and sharing information with other agriculture programs. Therefore, there is no formal report of
This result is in line with (Siregar \& Jeliwanti, 2017) research, which shows farmers' low cognitive level towards the RFI program in Selayu Village, Turen District, Malang Regency. The main factor of this result 
is mainly because the socialization of the RFI program is still lacking. Most farmers in this study site only participate in the program because they follow the recommended RFI program's government officers. Farmers do not understand much about the RFI program and only hand it over to the farmer group management.

\section{The affective attitude of farmers}

The Affective Attitude (AA) is a component associated with pleasure or dislike showing how farmers' emotional feelings to the RFI program. Table 4 shows the AA level of farmers towards the RFI program. In general, this table shows that farmers who made claims the insurance of damage of their paddy field and has stopped to join the program are mostly neutral to the program. This neutrality shows that farmers could not determine exactly their assessment of the RFI program. Farmers still doubt whether they liked it or not.

This condition is mainly because they only receive the programs given by the agriculture office in the beginning. They think the program has been arranged very well by the government. to farmers, the time lag is very close, making it difficult for farmers to sign the RFI program's continuation. Furthermore, farmers who do not participate in this program have very-low AA to the premium paid, which means that farmers do not like the amount of compensation paid in this RFI program, whether it is the number of initial and after subsidies. This low AA because farmers do not know precisely about the program's benefits.

This finding is relatively distinct from Siregar \& Jeliwanti (2017) research in Selayu Village, Malang Regency, and Suciani \& Ranti (2018) in Jambi. Siregar \& Jeliwanti (2017) found farmers have a moderate level of AA to the RFI program. Farmers feel that the RFI program can overcome the risk of rice farming risks that farmers might experience. Meanwhile, Suciani \& Ranti (2018) found that the farmers' affective was positive/high for the RFI program, which meant that most farmers accepted and agreed with the RFI program.

On the contrary, the AA level of farmers in Tanah Datar District is still neutral because there are several things from the RFI program that are liked and disliked by

Table 4. The affective attitude of farmers towards the RFI program

\begin{tabular}{|c|c|c|c|c|c|c|}
\hline \multirow[b]{2}{*}{ No } & \multirow[b]{2}{*}{ Categories } & \multicolumn{4}{|c|}{ The affective attitude of farmers to each object of RFI program } & \multirow[b]{2}{*}{$\begin{array}{l}\text { Affective } \\
\text { Total }\end{array}$} \\
\hline & & $\begin{array}{l}\text { Benefit } \\
\text { program }\end{array}$ & $\begin{array}{l}\text { The premiums } \\
\text { paid by farmers }\end{array}$ & $\begin{array}{l}\text { Mechanically } \\
\text { RFI }\end{array}$ & $\begin{array}{l}\text { Service of } \\
\text { RFI }\end{array}$ & \\
\hline 1 & $\begin{array}{l}\text { Farmers who have claimed } \\
\text { the damage }(n=22)\end{array}$ & neutral & neutral & neutral & neutral & neutral \\
\hline 2 & $\begin{array}{l}\text { Farmers that have stopped the } \\
\text { RFI program }(n=83)\end{array}$ & high & neutral & neutral & high & neutral \\
\hline 3 & $\begin{array}{l}\text { Farmers who continue to } \\
\text { follow the RFI program } \\
(\mathrm{n}=12)\end{array}$ & high & high & neutral & high & High \\
\hline 4 & $\begin{array}{l}\text { New farmers who join the } \\
\text { program }(n=103)\end{array}$ & neutral & neutral & neutral & high & High \\
\hline 5 & $\begin{array}{l}\text { Farmers who do not follow } \\
\text { the RFI program }(n=21)\end{array}$ & neutral & Very low & neutral & neutral & neutral \\
\hline
\end{tabular}

There are two categories of farmers with high AA to the RFI program, the $3^{\text {rd }}$ and the $4^{\text {th }}$ category. Farmers in the $3^{\text {rd }}$ category have a high AA to the RFI program, especially on the object attitude of the benefit, the premiums, and the RFI program's services. This AA level at least shows why farmers in this category have applied back for the RFI program.

Categories farmers who quit are less like the mechanism RFI program that during one growing season. According farmers so that the total farmers have not been able to determine their attitude 


\section{The conative attitude of farmers}

The conative (behavioral) attitude (CONA) is a component of attitudes connected to a person's overt actions to the RFI program. Table 5 shows the CONA level of farmers to the RFI program. In general, the table shows the CONA level of farmers to the RFI program is relatively high.
Timur District. She confirmed that most farmers wanted to participate in the rice farming insurance program in their lowland rice farming. However, it is different from the results of Siregar's research (2017) in Malang regency, where farmers have a Low conative attitude to the RFI program, which means they are not willing to participate in the RFI program. Farmers feel that the RFI program, which requires $>75 \%$ damage intensity to claim

Table 5. The conative attitude of farmers to the RFI program

\begin{tabular}{|c|c|c|c|c|c|c|}
\hline \multirow[b]{2}{*}{ No } & \multirow[b]{2}{*}{ Categories } & \multicolumn{4}{|c|}{ The conative attitude of farmers to each object of RFI program } & \multirow[b]{2}{*}{$\begin{array}{l}\text { Conative } \\
\text { Total }\end{array}$} \\
\hline & & $\begin{array}{l}\text { Benefit } \\
\text { program }\end{array}$ & $\begin{array}{l}\text { The premiums } \\
\text { paid by farmers }\end{array}$ & $\begin{array}{l}\text { Mechanically } \\
\text { RFI }\end{array}$ & $\begin{array}{l}\text { Service of } \\
\text { RFI }\end{array}$ & \\
\hline 1 & $\begin{array}{l}\text { Farmers who have claimed } \\
\text { the damage }(n=22)\end{array}$ & high & neutral & neutral & high & neutral \\
\hline 2 & $\begin{array}{l}\text { Farmers that have stopped the } \\
\text { RFI program }(n=83)\end{array}$ & high & high & high & high & high \\
\hline 3 & $\begin{array}{l}\text { Farmers who continue to } \\
\text { follow the RFI program } \\
(n=12)\end{array}$ & high & Very high & neutral & high & high \\
\hline 4 & $\begin{array}{l}\text { New farmers who join the } \\
\text { program }(n=103)\end{array}$ & high & high & high & high & high \\
\hline 5 & $\begin{array}{l}\text { Farmers who do not follow } \\
\text { the RFI program }(n=21)\end{array}$ & high & high & high & high & high \\
\hline
\end{tabular}

All categories of farmers are willing to act to the program. Farmers want to search for information and guidance about the RFI program, from registration issues until the claims process if they fail with their farming. Only the $1^{\text {st }}$ category of farmers (farmers who have claimed the damage) tend to act classified as neutral. Farmers are still hesitant to find further information about the RFI program. They are also reluctant to join the AUTP program again due to disappointment in the damage claim process that was not according to schedule.

Farmers in the $3^{\text {rd }}$ category (farmers who are continuing to follow the RFI program) have a high CONA level. It may happen because farmers are already familiar with and are very friendly with the RFI program. Meanwhile, farmers who do not follow the RFI program ( $5^{\text {th }}$ category) also have a high CONA level. Although they do not follow the RFI program, farmers are willing to look for information and desire to follow the RFI program. It can happen because the farmers who still need information and knowledge related to the RFI program tend to fulfill the act and wish to follow the RFI program. These findings align with Suciani \& Ranti (2018), who found that high conative attitudes farmers towards the RFI program in Nipah Panjang Subdistrict, Tanjung Jabung damage, is complex, so farmers are less willing to act on the RFI program because these events rarely and will waste money. The discussion shows that farmers can have different conative attitudes depending on the program's mechanism.

\section{Relationship between socialization and farmers attitudes to the RFI Program}

The preceding discussion shows that awareness at the district level is formal and structured, while at the farm level, the socialization is done informally along with the regular meeting of extension workers in the field site. Theoretically, the socialization process should affect all three components of attitudes. In fact, formal socialization at the district level could only influence participants' cognitive attitudes to the level of Neutral. The expectation of influencing those three components of attitude at the farm level by the extension workers is not entirely successful.

The socialization process at the district and farm level has not changed farmers' knowledge and confidence towards the RFI program. Farmers got a piece of knowledge about the RFI program without having the complete information and knowledge. For example, farmers know that they need to pay a premium on the premium paid, but 
they do not see the information about subsidized premium and independence premium. Most farmers also have only a Neutral level of affective attitudes (Table 4.). The socialization process still did not make farmers have sufficient cognitive skills towards the RFI program, making them unable to determine their RFI program's feelings. Do they like or dislike the RFI program? Because their knowledge is incomplete. However, most farmers' conative or willingness to act is at a High level, meaning that they are willing to join the RFI program even though the information given to them is still incomplete.

\section{CONCLUSIONS AND RECOMMENDATIONS}

\section{Conclusion}

There are two important conclusions from this study. First, a formal socialization program at the District level and informal socialization at the farm level did not effectively influence all categories of farmers' cognitive and affective attitudes to a high level.

Second, farmers' affective attitude components are at a neutral level, which means farmers cannot determine their attitude toward the RFI program, whether they like or dislike an RFI program to overcome the risks of farming in agriculture. Conative attitudes of farmers who have claimed the insurance of the damage are mostly Neutral. It shows that the RFI program could not make farmers confident with this program, mainly due to the uncertainty of fairness and smoothness of claiming process.

\section{Recommendation}

The socialization should be done intensively at the farm level, through formal and informal farmers' groups. The extension worker should be trained intensively to be a partner of farmers to decide and organize the RFI activities at the farm level.
There is a need to improve services and regulations to be more explicit and straightforward for farmers' level of knowledge. Service improvement is also necessary because it will allow farmers to re-join the program in the next planting season, where farmers already have a high level of knowledge (cognitive) and feelings (affective).

\section{REFERENCES}

[BPTPHP] Balai Perlindungan Tanaman Pangan Hortikultura dan Perkebunan Provinsi Sumatera Barat. 2017. Laporan Tahunan 2016. Padang: BPTPHP.

[DTPHP] Dinas Tanaman Pangan Hortikultura dan Perkebunan Provinsi Sumatera Barat. 2016. Laporan Pelaksanaan Program Asuransi Usahatani Padi di Provinsi Sumatera Barat Tahun 2016. Padang: DTPHP.

Pasaribu. 2014. Food production risks: Challenges and opportunities. Ministry of Agriculture.

Siregar, \& Jeliwanti. 2017. Farmers' Perceptions and Responses to the Implementation of Rice Farming Insurance Program in Selayu Village, Turen District, Malang Regency. Universitas Brawijaya, Faculty of Agriculture.

Suciani, \& Ranti. 2018. Relationship between Farmers' Attitudes and the Implementation of the Rice Farming Insurance Program in Nipah Panjang District, Tanjung Jabung Timur Regency. Journal of Agribusiness Study Program.

Walgito, B. 2003. Introduction to General Psychology. Yogyakarta: Andi Offset. 